\title{
A Nonlinear Static Research on A G+5 Storey Existing RC Structure Under Seismic Loading
}

\author{
V. Sai Kiran Kumar, C. Mahalingam, M. Shiva Rama Krishna
}

\begin{abstract}
A six-story reinforced concrete structure area to a seismic hazard can be analyzed; as soon as the member has yielded, the plastic hinge will likely be used to symbolize the mode of failure in the beams and columns. The pushover analysis is carried out on constructing utilizing an identical static process from ETABS-2016 and IS 1893-2016. The analysis is regulated through efficiency-situated warmness engineering legal guidelines, even as an inelastic structural evaluation is combined with seismic hazard to calculate the expected seismic performance of the structure. The building's basis shear $v / s$ roof strain curve referred to as the pushover curve is an enormous consequence of pushover evaluation; nonlinear dynamic evaluation is carried out in both respects $(X \& Y)$. Default hinge facets to be had in precise packages are built-in for every member in step with FEMA-440(Federal Emergency management agency) and ATC-40(applied technology Council) for every member.

Keywords: Plastic hinge, pushover analysis, ETABS, base shear, FEMA-356, FEMA-440, ATC-40.
\end{abstract}

\section{INTRODUCTION}

The seismic impact will annihilate a building and will also lead to several problems such as tsunamis liquefaction of soil, landslides etc. As per IS: 1893- 2016 code and seismal design regulations which were recently released were in use effective ever since. For the alternate structures of the sensing of buildings, this code gives minimum loads required [1]. Majority of engineers adopt linear analysis technique as it is easy while computing \& analyzing the structure. This method resorts uses of response reduction parameter for the entire structure to give a nonlinear response of the structure. The building standards such as ATC and FEMA have applied on the design criteria based on the performance based, which will estimate the nonlinear response of the building.An insight into the structural elements that regulate efficiency during serious earthquakes can be provided in this assessment. During layout earthquake movement, a thermal deficient construction will be exposed to inelastic intervention. It is the only way to portray the structure's real behavior during the earthquake.The building changes the structure's conduct during the earthquake as shown below.

Revised Manuscript Received on July 10, 2019.

V. Sai Kiran Kumar, P.G Student, Vignan's University, Guntur, Andhra Pradesh India. (Email: saikiran.vukanti@gmail.com)

C. Mahalingam, Assistant professor, Vignan's University, Guntur, Andhra Pradesh India. (Email: akcmahalingam@gmail.com)

M. Shiva Rama Krishna, Assistant professor, Vignan's University, Guntur, Andhra Pradesh India. (Email: shivaram.vu@gmail.com)

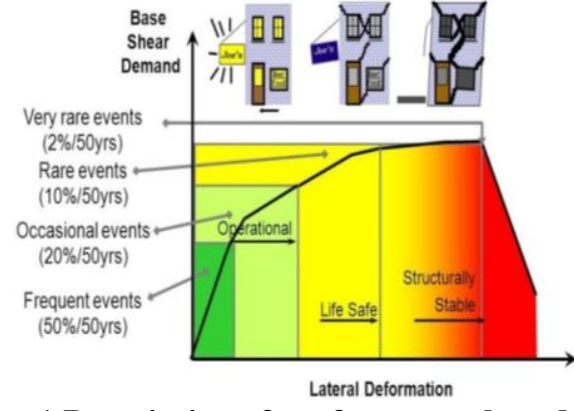

Figure: 1 Description of performance-based design

A system is usually built in a powerful column and soft beam concept, but the principle is obeyed in frequent techniques such as tiny constructions to face the implications.A framework can achieve a stronger outcome during the incident based on the ATC - 40 and FEMA-440 code manual.

MehmetInel and HayriBaytanOzmen (2006) User-defined nonlinear hinge characteristics and standard hinge characteristics as per ATC 40 and FEMA-440[2] were used to perform pushover assessment on a 4 and 7-story construction. The fundamental purpose of this paper is to investigate the double differences in pushover analysis outcome because of default and consumers are defending nonlinear component aspects.

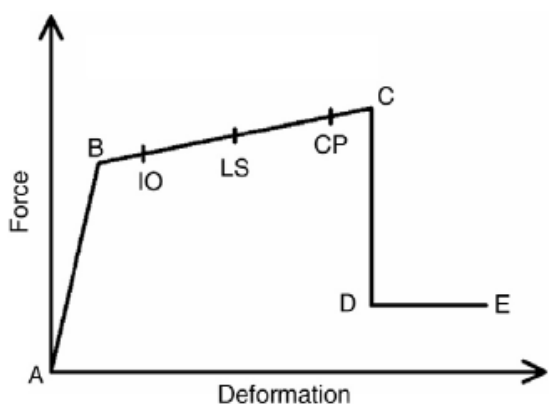

Figure: 2 Force Deformation curve

Table 1: Performance of Structure damage level

\begin{tabular}{|l|l|}
\hline Performance stages & \multicolumn{1}{|c|}{ Statements } \\
\hline Immediate Occupancy & Little damage, very big parts drop. \\
\hline Life Safety & $\begin{array}{l}\text { Substantial to severe harm, big } \\
\text { and widespread splits in all } \\
\text { employees and non-structural } \\
\text { components entity malfunction. }\end{array}$ \\
\hline
\end{tabular}

Published By:

Blue Eyes Intelligence Engineering 


\begin{tabular}{|l|l|}
\hline Preventing Failure & $\begin{array}{l}\text { Very massive harm, big } \\
\text { displacement, very little rigidity } \\
\text { and resistance but execute } \\
\text { loading column and wall } \\
\text { bearings, complete destruction } \\
\text { or near complete failure. }\end{array}$ \\
\hline
\end{tabular}

\section{STRUCTURAL MODELING:}

AutoCAD drafts all beams and column members imported into ETABS. The loads and properties are assigned to the considered reinforced concrete structure. The plan considered as described below as shown fig 3. The overall dimensions of the plan are $70.27 \mathrm{~m} \times 60.37 \mathrm{~m}$. In this existing $\mathrm{RC}$, a building is used as a commercial complex purpose.

\section{I) Description of building:}

a. Concrete grade: M30,

b. Steel grade: $\mathrm{Fe}-415 \mathrm{~N} / \mathrm{mm}^{2}$

Table: 2 Cross Section dimensions

\begin{tabular}{|l|l|l|}
\hline Member & Width $(\mathbf{m m})$ & Depth $(\mathbf{m m})$ \\
\hline B1 & $\mathbf{3 0 0}$ & $\mathbf{5 0 0}$ \\
\hline B2 & 350 & 750 \\
\hline C1 & 300 & 850 \\
\hline C2 & 300 & 650 \\
\hline
\end{tabular}

II) Seismic Coefficients

\begin{tabular}{|c|l|c|}
\hline S.No & \multicolumn{1}{|c|}{ Parameters } & $\begin{array}{c}\text { Code } \\
\text { Provisions }\end{array}$ \\
\hline 1 & Type of Structure & RCC \\
\hline 2 & Nature of Building & $\begin{array}{c}\text { University } \\
\text { Building }\end{array}$ \\
\hline 3 & Damping of Concrete & $5 \%$ \\
\hline 4 & Importance Factor & 1.5 \\
\hline 5 & Response Reduction Factor & 5 \\
\hline $6 . \mathrm{a}$ & Existing Seismic Zone & III \\
\hline $6 . \mathrm{b}$ & Considered Seismic Zone & IV \\
\hline 7 & Earthquake force in X direction \\
\hline 8 & Earthquake force in Y direction \\
\hline
\end{tabular}

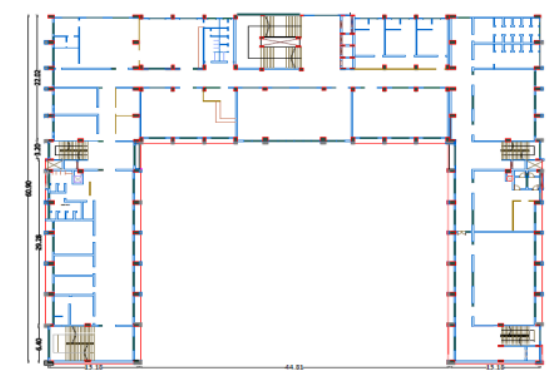

Figure: 3 AutoCAD Structural plan

\section{METHODOLOGY:}

The present work is to be taught the seismic behaviour of a G+5 storey RCC building having diaphragm discontinuity and geometrical irregularities under pushover analysis. The methodology, which is performed, is briefly described beneath.

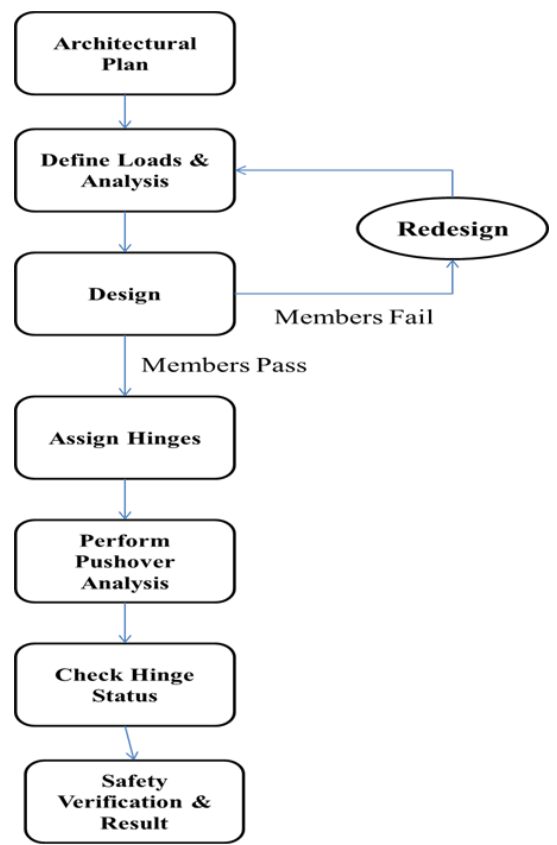

Figure: 4 Diagram of methodology stream

\section{NONLINEAR STATIC ANALYSIS:}

* This evaluation is theoretically right, but very difficult and not suitable for all models.

* Structural engineering practice nowadays utilizes a nonlinear static evaluation, a replacement technique for solving the issue.

* The lateral strain may portray the range of base distortion caused by earthquake.

* The output generates a static pushover curve plotting a deflection parameter based on force.

* Basically split into three kinds in this study

a. Target displacement

b. Capacity spectrum method

c. Coefficient method.

* These three methods are used during the earthquake to determine the effectiveness of the building and to achieve very pleasantly accurate results.

\subsection{Plastic Hinge:}

* The plastic hinge is the primary component of the framework when each load is given to the structural parts.

* In this structure, each participant assigned a hold of 5\% of each joint (if the structure is periodic in a type).

* If beams and pillars are not of the same length, 5\% of the joint was not used by each structural component.

* We need to use ASCE-41-13 code manual to assign the handles.

* Hinge shows the member's breakdown and the member's place.

\subsection{Building Performance level:}

* Construction that primarily performs three requirements i.e.

- Immediate occupancy level

- Life safety level

- Collapse prevention 
* In the earthquake motion, these three play a significant role.

* Resisting lateral distortion, as shown below, to be verified against the normal deformation boundaries.

\section{Table: 3 Deformation limits}

\begin{tabular}{|l|l|}
\hline State of Damage & Chord Rotation Capacity \\
\hline Immediate Occupancy $(\mathrm{IO})$ & $\Theta_{\mathrm{y}}+10 \%$ of $\left(\Theta_{\mathrm{u}}-\Theta_{\mathrm{y}}\right)$ \\
\hline Life Safety $(\mathrm{LS})$ & $\Theta_{\mathrm{y}}+60 \%$ of $\left(\Theta_{\mathrm{u}}-\Theta_{\mathrm{y}}\right)$ \\
\hline Collapse Prevention $(\mathrm{CP})$ & $\Theta_{\mathrm{y}}+90 \%$ of $\left(\Theta_{\mathrm{u}}-\Theta_{\mathrm{y}}\right)$ \\
\hline
\end{tabular}

\section{ANALYTICAL DESIGN:}

* As shown in figure 5, a 3D design was developed to handle the corresponding static assessment and pushover evaluation.

* Compared to nonlinear static assessment, equivalent static assessment has a lower displacement.

* After gradually implementing it to the current construction (deemed building / structure), some portion of the structure will fail.

* Considered the current Zone-III situation structure but its shift from Zone-III to Zone-IV for this initiative.

* Because the house can survive in Zone IV situation in that situation, there is no question that in Zone-IV it can withstand.

* The construction methods move aside after completing all preliminary measures to show the path of the earthquake.

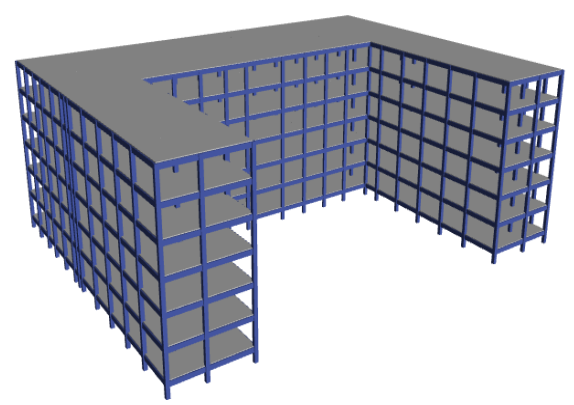

Figure: 5 3D Structural Model

* New support for withstands more earthquake (seismic) charging to this framework.

* Usually, different kinds of bracings are used, here two kinds are used.

ii. $\Lambda$ - bracings

* As shown in Figure 6.a, 6.b, these two are styled and layout regarded.

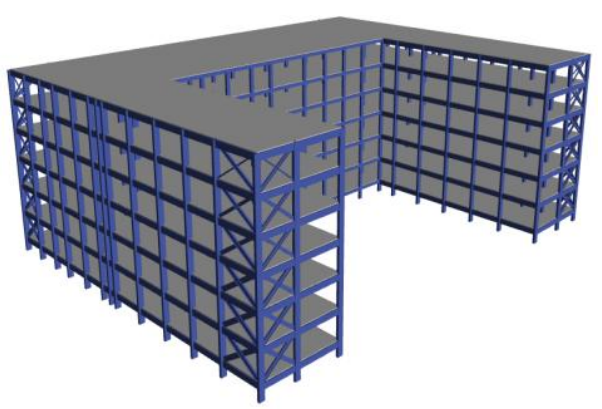

Figure: 6.aX - bracing 3D model i. $\mathrm{X}$ - bracings

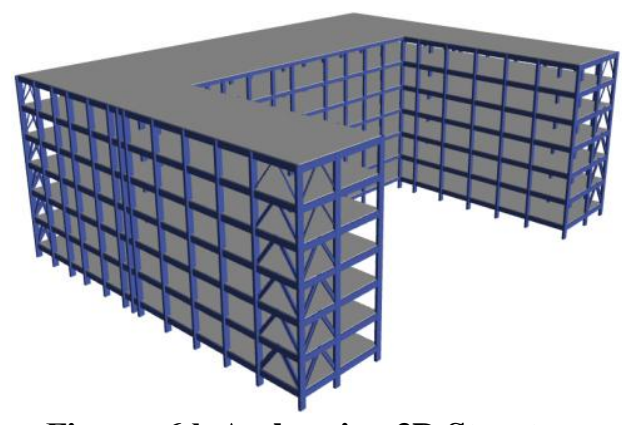

Figure: 6.b $\Lambda$ - bracing 3D Structure

\section{FINAL RESULTS \& DISCUSSIONS:}

* This building's capacity curve is shown in Fig. 7. This curve reflects worldwide behaviour, stiffness, and plasticity.

* Capacity range technique offers accurate and simple process efficiency.

* The capability range and request ratio curves this phenomenon called the quality point.

* When the supply curve and capability range meet at a stage at which point the power of the framework (quality point) is indicated.

* X-bracings have a morebase strain compared to the foundation strain in both bracings (X, some-bracings).

* Now we can see the outcomes of the hinge as shown in the picture below, which shows the place of the member load.

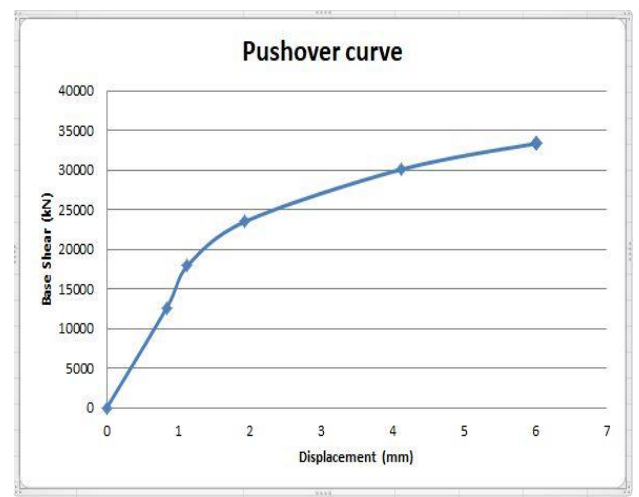

Figure: 7.a Capacity curve

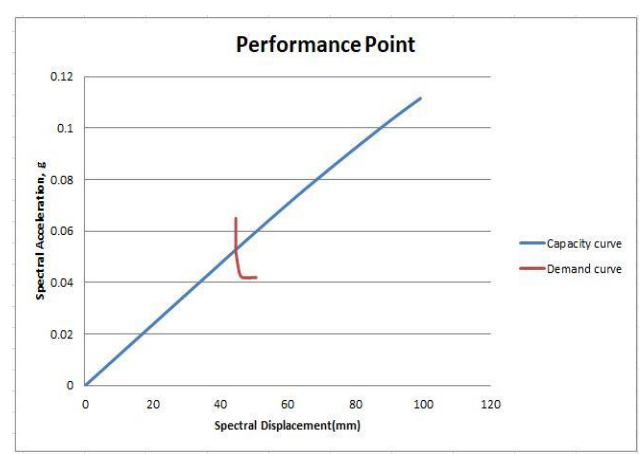

Fig: 7.b Performance point 


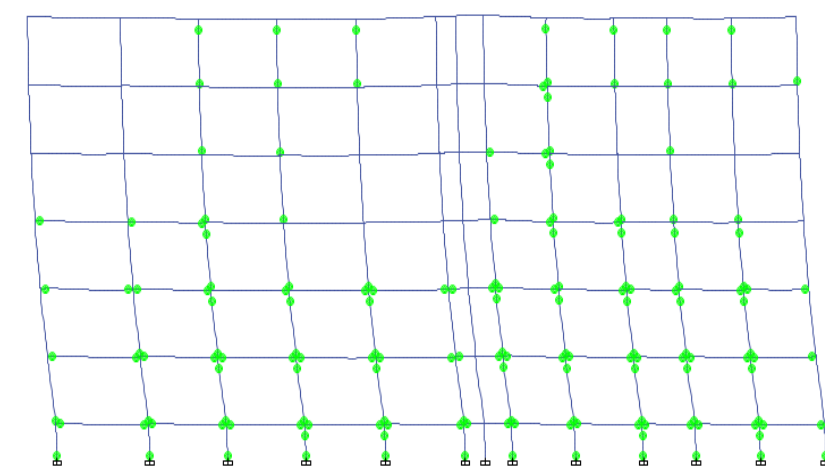

Fig: 7.c Hinge locations in Structure

Max. Storey displacement:

The highest storage limit for linear static technique is when the earthquake force is transferred to the structure's $\mathrm{X}$ $\& \mathrm{Y}$ coordinates as shown in the graphics below.

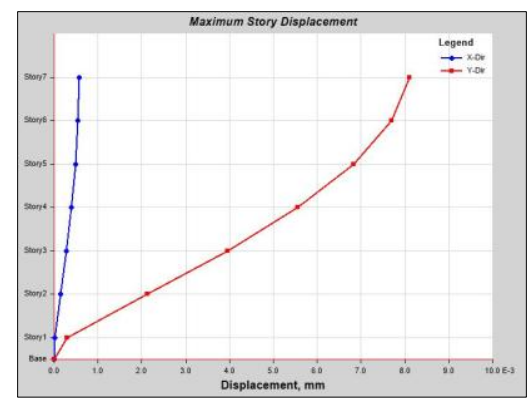

Max. Storey Drift:

The max storey drift for equivalent static method is when the seismic force is applied on both directions are represented as follows:

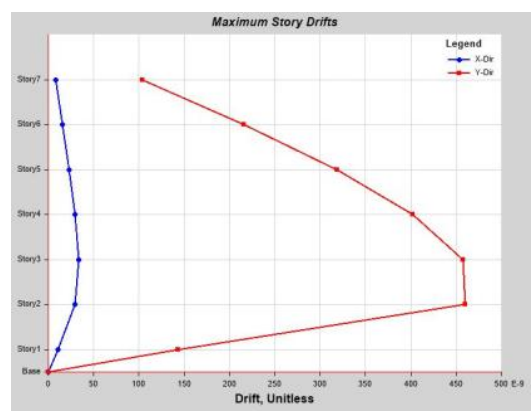

Max storey shear:

For the duration of the earthquake, the peak floor shear occurs as follows beneath fig.

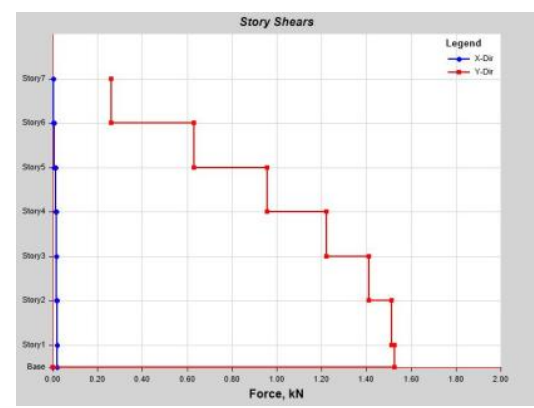

Fig: 8 Storey Shear

Table:4 Shear Force in table representation

\begin{tabular}{|c|c|c|c|c|c|}
\hline $\begin{array}{c}\text { Load } \\
\text { Case }\end{array}$ & $\begin{array}{c}\text { FX } \\
(\mathrm{kN})\end{array}$ & $\begin{array}{c}\text { FY } \\
(\mathrm{kN})\end{array}$ & $\begin{array}{c}\text { MX } \\
(\mathrm{kN}-\mathrm{m})\end{array}$ & $\begin{array}{c}\text { MY } \\
(\mathrm{kN}-\mathrm{m})\end{array}$ & $\begin{array}{c}\text { MZ } \\
(\mathrm{kN}-\mathrm{m})\end{array}$ \\
\hline Live & 0 & 0 & 1365455 & -1411225 & $9.48 \mathrm{E}-06$ \\
\hline
\end{tabular}

\begin{tabular}{|l|l|l|l|l|l|}
\hline EQX +ve & -7637.47 & $-5.5 \mathrm{E}-07$ & $2.61 \mathrm{E}-05$ & -154218 & 250530.8 \\
\hline
\end{tabular}

\begin{tabular}{|l|c|c|c|c|c|}
\hline EQY +ve & 0 & -5881.29 & 118757 & $-4 \mathrm{E}-06$ & -203659 \\
\hline
\end{tabular}

\begin{tabular}{|l|l|l|l|l|l|l|}
\hline EQX-ve & -7637.47 & $-5.5 \mathrm{E}-07$ & $2.61 \mathrm{E}-05$ & -154218 & 250530.8 \\
\hline
\end{tabular}

\begin{tabular}{|c|c|c|c|c|c|}
\hline EQY-ve & 0 & -5881.29 & 118757 & $-4 \mathrm{E}-06$ & -203659 \\
\hline
\end{tabular}

Table: 5 Base shear and Roof displacement at performance levels

\begin{tabular}{|c|c|c|c|c|c|c|c|c|c|c|c|c|}
\hline Steps & $\begin{array}{c}\text { Roof } \\
\text { Displacement } \\
(\mathrm{mm})\end{array}$ & $\begin{array}{c}\text { Base } \\
\text { force }(\mathrm{kN})\end{array}$ & A-B & B-C & C-D & D-E & $>\mathrm{E}$ & A-IO & B-LS & $\mathrm{C}-\mathrm{CP}$ & $>\mathrm{CP}$ & Total \\
\hline 1 & 0.284 & 0 & 6524 & 0 & 0 & 0 & 0 & 6524 & 0 & 0 & 0 & 6524 \\
\hline 2 & 0.841 & 12649.2226 & 6522 & 2 & 0 & 0 & 0 & 6524 & 0 & 0 & 0 & 6524 \\
\hline 3 & 1.131 & 17929.5128 & 6484 & 40 & 0 & 0 & 0 & 6524 & 0 & 0 & 0 & 6524 \\
\hline 4 & 1.936 & 23503.3939 & 6328 & 196 & 0 & 0 & 0 & 6522 & 0 & 0 & 2 & 6524 \\
\hline 5 & 4.123 & 30082.7139 & 6142 & 382 & 0 & 0 & 0 & 6522 & 0 & 0 & 2 & 6524 \\
\hline 6 & 6.013 & 33360.7045 & 6012 & 512 & 0 & 0 & 0 & 6520 & 0 & 0 & 4 & 6524 \\
\hline 7 & 6.013 & 33359.3023 & 6012 & 512 & 0 & 0 & 0 & 6520 & 0 & 0 & 4 & 6524 \\
\hline 8 & 6.014 & 33361.0818 & 6012 & 512 & 0 & 0 & 0 & 6520 & 0 & 0 & 4 & 6524 \\
\hline 9 & 6.018 & 33367.3647 & 6012 & 512 & 0 & 0 & 0 & 6520 & 0 & 0 & 4 & 6524 \\
\hline 10 & 6.018 & 33366.7351 & 6012 & 512 & 0 & 0 & 0 & 6520 & 0 & 0 & 4 & 6524 \\
\hline
\end{tabular}




\section{VII.CONCLUSION:}

In this study, the primary job is to use a nonlinear static assessment to obtain the seismic efficiency of construction. This study's conclusion can be described as below.

* Pushover analysis could be a comparatively easy method of monitoring the building's nonlinear behaviour.

* The technique of capability range shows the building's complete power against collapse, which is large and there is an adequate supply of power and displacement.

* The technique of capability range shows the building's complete power against collapse, which is large and there is an adequate supply of power and displacement. [7].

* The final conclusion for this project linear static method is good enough to only low to medium height buildings with regular confirmation.

* The considered model of building resists major seismic forces.

* Analysis of pushover could be a comparatively easy way to track the building's nonlinear behavior.

* A critical reason is found, that's the immediate occupancy level condition. In that area structure have minor visible cracks obtain.

* The structure can behave resisting major earthquake forces throughout the imposed seismic excitation.

* Inverted ' $v$ ' $(\Lambda)$ is an inexpensive and excellent lateral load resistant to compare with $\mathrm{X}$-bracing design.

\section{REFERENCES:}

1. IS 1893-2016, "Indian Standard Criteria for Resistant Design of Earthquake Structures: General Supply and Building," Indian Standards Bureau, New Delhi.

2. MehmetInel and HayriBaytanOzmen, "Nonlinear Analysis of Reinforced Concrete Buildings Effects of Plastic Hinge Properties" Engineering Structures, Vol.28, 2006, pp. 1494 1502.

3. Golghate Kavita, Baradiya Vijay and Sharma Amit, "Reinforced Concrete Building Pushover Analysis of 4 Storey"International Journal of Latest Trends in Engineering and Technology, Vol. 2, May 2013, pp. 80-84.

4. "Nonlinear Structural Analysis for Seismic Design," A Guide for Practical Engineers, National Standards and Technology Institute, Gregory G. Deierlein, Andrei M. Reinhorn, Michael R. Willford.

5. ATC40-"concrete building seismic assessment and retrofitting.

6. 'FEMA 356 (2000) ' Seismic Building Rehabilitation Standard and Commentary, ' Federal Emergency Management Agency, Washington, DC, USA.

7. R. A. Hakim, S. A. Ashour, M. S. Alama. "RC Building Seismic Assessment According to ATC 40, FEMA 356 and FEMA 440," Arab Journal for Science and Engineering, 2014.

8. FEMA-440, Federal Emergency Management Agency, Applied Technology Council (ATC-55 Project) 201 Redwood Shores Parkway, Suite240, Redwood City, California, Federal Emergency Management Agency Washington D.C. 